ROCZNIKI HUMANISTYCZNE

Tom LXVIII, zeszyt $12-2020$

DOI: https://doi.org/10.18290/rh206812-14

STANISŁAW DĄBEK

\title{
GLOSY DO BADAŃ MONIUSZKOWSKICH
}

„Moniuszko potrafił w swej twórczości wznieść się na wyżyny dostępne w okresie romantycznym tylko wielkim talentom i był twórcą europejskim."

Bogusław Schaeffer, 1987
„(...) przepojenie swojej muzyki duchem ludowej twórczości religijnej, której natchnienia znajdziemy w jego najbardziej wyrafinowanych dziełach, jak Litanie Ostrobramskie (...)" 1

Witold Rudziński, 1995

Oba stwierdzenia: awangardowego kompozytora i (cytującego go) kompozytora-badacza Moniuszki dotyczą jego dzieła. Pozbawione apologizowania, uświadamiają po prostu jego wartość - wielką osobowość twórczą wraz z wyrafinowaniem. Stanowią celne przesłanie dla tego tekstu poświęconego problematyce dzieła.

Prof. dr hab. STANISŁAw DĄBEK - em. prof. Uniwersytetu Muzycznego Fryderyka Chopina w Warszawie; adres do korespondencji: ul. Wrocławska 24, 20-730 Lublin; e-mail: dabeks@wp.pl.

Prof. Dr. habil. STANISŁAW DĄBEK - retired professor, The Fryderyk Chopin University of Music; address for correspondence: ul. Wrocławska 24, 20-730 Lublin, Poland ; e-mail: dabeks@wp.pl.

${ }^{1}$ Rudziński 160; cytat z Schaeffera także za Rudzińskim (170-171). Ten najwybitniejszy moniuszkolog, w okresie PRL-u nie mógł pisać szerzej (np. w monografii) o muzyce religijnej Moniuszki. Nierzadko w jego teksty z pewnością ingerował cenzor, wprowadzając do stwierdzeń autora wartościujących ten gatunek oceny negatywne (np. „twórczość religijna Moniuszki miała charakter wybitnie marginesowy i wyłącznie użytkowy”). Natomiast ten artykuł ponad 80-letniego badacza prezentuje jego rozległą wiedzę i przywraca w pełni własną, wysoką ocenę muzyki religijnej Moniuszki; wnosi duże wartości badawcze. Nie został jednak uwzględniony „wśród prac powstałych w II poł. XX w.” w opublikowanym ostatnio artykule Marka Bebaka. Tym bardziej, że autor wymienia, bez kryterium wartości badawczej i koniecznej selekcji, m.in. prace licencjackie, magisterskie i popularne. Być może dlatego, że nie zajmował się problematyką moniuszkowską, zwłaszcza jego dziełem, co jest widoczne. Na przykład w zakończeniu artykułu, zamiast omówienia jego rezultatów, dokonuje powierzchownych uogólnień, niewymagających badań, używając obiegowych zwrotów: [kompozycje religijne] „dość proste pod względem techniczno-muzycznym”, „utwory religijne mają również zwykle dość prostą fakturę”, itp. Posługując się identycznymi „kalkami”, podsumowuje też „człowieka”: „Moniuszkę możemy uznać za człowieka o prostym usposobieniu (...). Był poczciwym, dobrym człowiekiem” (Bebak 168). 


\section{LITANIE OSTROBRAMSKIE - „MUZYKA WOTYWNA” Z NOWYM WEZWANIEM SANCTA MATER}

W zdaniu kończącym moją monografię użyłem określenia „modlitwa wotywna” w wymiarze teologiczno-duchowym, nie rozwijając go: „Można by więc Litanie Ostrobramskie nazwać muzyczną błagalną modlitwą wotywną supplicatio votiva, rozważaniem Miłosierdzia Trójjedynego Boga i teologicznych przywilejów Ostrobramskiej Panny Świętej, łączącą ziemski, widzialny i duchowy wymiar kultu" (Twórczość litanijna 231).

W niniejszym tekście chcę powrócić do tego ważnego stwierdzenia. Zamierzam uzasadnić rozszerzenie wymiaru teologicznego o wymiar muzyczny. Uznać cztery Litanie Ostrobramskie nie tylko za „modlitwę wotywną”, ale także „muzykę wotywną.” "Muzyczne wotum” ku czci Ostrobramskiej Sanctae Matris Misericordiae. Litanie te zapewne nie powstały przypadkowo, lecz z wyraźnym zamierzeniem ${ }^{2}$, podobnie jak wota umieszczone w kaplicy Ostrobramskiej. Jak srebrny półksiężyc związany nierozerwalnie (od 1849 r., nota bene okresu tworzenia Litanii) z cudownym obrazem.

Dookreślenie Ostrobramska, występujące w tytule utworu, ukierunkowuje związek dzieła z litanią jako centrum liturgii na liturgię sprawowaną w kaplicy w Ostrej Bramie w ramach kultu Maryi - Matki Miłosierdzia. Jakkolwiek w korespondencji Moniuszki znajdujemy jedynie kilka lakonicznych wzmianek, brak też jednoznacznej, ,werbalnej” genezy litanii.

Można jednak założyć, że kompozytor ustalił liturgiczne przeznaczenie dzieła. Jak napisał w liście (wrzesień 1854): „Trzecia litanię mamy wykonać (...) w naszej Ostrobramskiej kaplicy" (Rudziński, Listy 200). Podobnie Witold Rudziński sugeruje związek Litanii z liturgią: „Myśl zatytułowania ich «Ostrobramskimi» narodziła się zapewne pod wrażeniem nabożeństw maryjnych i październikowych w kaplicy Matki Boskiej Ostrobramskiej (...) mógł (...) obserwować i odczuwać ten szczególny nastrój nabożeństw, w których uczestniczył lud, stojący na ulicy" (Twórczość maryjna 161). Ze wspomnianych nabożeństw maryjnych przypomnijmy główne, doroczne święto listopadowe (16.) Opieki Najświętszej Maryi

\footnotetext{
${ }^{2}$ Tę problematykę metodologiczną podjąłem w artykule Missa de Lisieux Feliksa Nowowiejskiego - wotum ku czci św. Teresy (w druku). Jako główne atrybuty wotywne wyróżniłem: 1. tytuł kompozycji, 2. okoliczności związane z genezą utworu, np. określone konteksty, 3. inskrypcję, dedykację lub intencję kompozytora, 4. symboliczne atrybuty wotywne w utworze. Podkreślając, że „W ogóle intencja wotywna kompozytora zakłada jego szczególny, duchowy związek z dziełem jako wotum". W niniejszym artykule wykorzystam również dotychczasowe ustalenia badawcze mojej monografii oraz artykułu podsumowującego (Nowa metodologia 398-402), ograniczając się do cytowania obu prac jedynie w koniecznych przypadkach.
} 
Panny, z liturgią obejmującą wykonanie litanii. Także Tomasz Zan, w cytowanym wielokrotnie liście do Moniuszki (z 8 grudnia 1846 r.), nawiązuje do liturgii, prosząc o napisanie „porządnego akompaniamentu do (...) litanii śpiewanych w Ostrej Bramie" (Walicki, Stanistaw Moniuszko 65).

Zatem zarówno tytuł, jak i intencja kompozytora spełniają jedno z kryteriów uznania wszystkich czterech litanii za rodzaj „muzyki wotywnej.” Właśnie ich liczba wskazuje intencję kompozytora - nie jednorazową i raczej nieprzypadkową, tworzenia tych dzieł.

Ważnym kryterium dopełniającym, dotychczas nieuwzględnianym w badaniach moniuszkowskich, jest długa tradycja kultu Ostrobramskiej Matki Miłosierdzia. Jej omówienie zawiera monografia. W tradycję tę wpisuje się polska poezja ostrobramska (od XVIII wieku), także pieśniowa (nierzadko anonimowa, jak poniżej), przeniknięta wezwaniami Litanii loretańskiej, niekiedy przekształcanymi poetycko, np. „W tej Ostrej Bramie słynącą cudami/Jutrzenka Niebios jaśnieje nad nami."

Warto też mieć świadomość koneksji litanijnych (i generalnie religijnych) w polskiej poezji romantycznej, także wieszczów, o czym świadczą, wymieniając wielkie dzieła, Litania pielgrzymska (1832) Mickiewicza i Do Najświętszej Panny Maryi Litania (1852) Norwida ${ }^{3}$. Widoczny staje się pewien paradoks. Z jednej strony schyłek tworzenia litanii jako formy muzycznej w I poł. XIX wieku, z drugiej - zakorzenienie w świadomości społecznej poezji litanijnej. Także - istnienia rodzaju enklawy litanii $\mathrm{w}$ codziennej liturgii w kaplicy Ostrobramskiej. Jest to zrozumiałe, ponieważ wraz z kultem została wprowadzona i spopularyzowana przez karmelitów bosych wspomniana łacińska Litania loretańska odmawiana lub śpiewana. Nie przypadkiem jej liczne wezwania w polskim tłumaczeniu umieszczone na ozdobnych tabliczkach wypełniają ściany kaplicy.

Kolejne kryterium dopełniające, również nieuwzględniane dotychczas, tworzy pobożność romantyczna - indywidualna (osobowa) o rodowodzie ludowym. „Przeżywana wyjątkowo ekspresyjnie i w bezpośredni sposób. Wiązała się z przejawami reprezentatywnych wówczas kultów (np. Dzieciątka Jezus) oraz typowych dla tradycji ludowej praktyk pobożnościowych" (Twórczość litanijna $24 \mathrm{nn}$.), np. nabożeństwa Gorzkich żalów ${ }^{4}$. To „przepojenie (...) muzyki duchem ludowej twórczości

\footnotetext{
${ }^{3}$ Rozwinąłem tę problematykę (zamieszczając także literaturę) w artykule Muzyka kościelna Stanisława Moniuszki: gatunek - typologia - funkcja - aksjologia (w druku).

${ }^{4}$ Moniuszko zharmonizował trzy melodie z tego nabożeństwa w opublikowanym zbiorze Pieśni Naszego Kościoła z harmoniq Stanisława Moniuszki na organy ułożone i do grania przy Mszy czytanej przeznaczone w Warszawie nakładem autora [pierwodruk 1862]. Wymienia jedynie pieśń o incipicie Gorzkie żale, tzw. „Pobudkę.” Jednak do tego nabożeństwa należała też pieśń
} 
religijnej” jak to trafnie określił Rudziński w przywołanym cytacie, miało istotny wpływ na „wyrafinowany” styl Litanii Ostrobramskich.

Jednak kryterium szczególne tworzy koncepcja kompozytorska Moniuszki łącząca też aspekt teologiczny. Jednym z jej istotnych założeń są symboliczne atrybuty wotywne (ważne kryterium „muzyki wotywnej”), świadomie tworzone przez kompozytora. Zostały one uwzględnione w monografii wówczas jeszcze bez tego określenia, w kluczowym, najobszerniejszym rozdziale zatytułowanym „Muzyczno-symboliczny aspekt Litanii Ostrobramskich”. Przywołajmy jeden z najbardziej reprezentatywnych atrybutów.

Rodzaj moniuszkowskiego muzycznego „autografu”, odwołującego się do Ostrobramskiej Matki Miłosierdzia, tworzy świadome wprowadzenie nowego wezwania maryjnego Sancta Mater (Liber Usualis 1691-1693) do liturgicznego tekstu w III Litanii Ostrobramskiej, w jej trzeciej części (Sancta Maria - Sancta Mater, ora pro nobis, Molto agitato, h); trudno wskazać taki przypadek w ówczesnej praktyce kompozytorskiej. Generalnie problematyka tekstu w $L i$ taniach Ostrobramskich nie była dotychczas dostrzegana, doceniana i analizowana. Rudziński w cytowanym artykule przytacza zdawkową wypowiedź Jachimeckiego o tekście III Litanii, dotyczącą jednak ogólniejszego kontekstu: „Nacisk największy położył w niej [Moniuszko] na część Sancta Maria, sancta mater genitrix [małe litery!] i następne wiersze (...) Ustęp ten wystrzela z muzyki kościelnej Moniuszki jak paradoks muzyczny" (Rudziński, Twórczość maryjna 170). Również o tej części w aspekcie jej szybkiego tempa wypowiadał się negatywnie Opieński, zaś bronił kompozytora Rudziński.

Badacze ci nie zwrócili także uwagi na wprowadzenie wspomnianego nowego wezwania. Jest ono również „tworzywem” dla innych nowych wezwań, o czym dalej. Takie pominięcie jest zapewne konsekwencją nieuwzględnienia w badaniach liturgicznej struktury tekstu Litanii loretańskiej/Litaniae Beatae Mariae Virginis. Problematyce tekstu poświęciłem osobny paragraf w monografii, omawiając jego trzyczęściowy podział teologiczny. Dzięki niemu stała się widoczna skala ingerencji kompozytorskich obejmująca aż sześć typów, poza pominięciem, m.in. także kompilowanie wezwania z kilku sąsiadujących.

Ingerencje te wpisują się formalnie w przejaw upadku muzyki kościelnej wraz ze znanym, swobodnym stosunkiem do norm liturgicznych (czego Moniuszko nie tylko miał świadomość, lecz starał się o podniesienie jej pozio-

Rozmowa duszy, tzw. „Lament duszy nad cierpiącym Jezusem”, w zbiorze wymieniona osobno i na odległej stronie. Ta pieśń od drugiej wolty zawiera tekst jeszcze jednej pieśni z nabożeństwa Gorzkie żale o incipicie Badź pozdrowiony, badź pochwalony. Tych informacji nie zawiera komentarz dotyczący przeznaczenia pieśni z tego zbioru w artykule M. Bebaka (162-163). 
mu, o czym piszę w monografii oraz w artykule (zob. przyp. 3). Poznając analitycznie muzykę religijną Moniuszki, można jednak sądzić, że kompozytor postąpił tak w sposób przemyślany. Mówiąc poglądowo, dla niego tekst liturgiczny był tworzywem do „komponowania” rodzaju indywidualnej modlitwy, jak się wydaje, w duchu wspomnianej pobożności romantycznej. Dowodzą tego teksty różnych form moniuszkowskiej muzyki kościelnej z licznymi i nierzadko dużymi ingerencjami. Świadczą równocześnie o wyjątkowej wrażliwości kompozytora na słowo - „logos” w rozumieniu biblijnym i jego sens symboliczny (,,Tekst” a ,stowo" - w druku).

Nowe wezwanie Sancta Mater zostało wprowadzone w celu, można sądzić, eksponowania w całej części przymiotu „Matki”. Jednoczy on równocześnie inne przymioty - „Rodzicielki” i „Matki Boga”, obrazując sposób „komponowania” nowej modlitwy przez kompozytora. Tak więc wymienione - Sancta Mater Genitrix zostało utworzone z przekształconego Sancta Dei Genitrix. Natomiast wprowadzone także - Sancta Mater Dei powstało z dodania słowa Dei.

Dopiero patrząc całościowo na te zabiegi stosowane w trzeciej części III Litanii i - co najistotniejsze - związane z nimi środki, widać precyzję i zarazem swobodę wyobraźni oraz wyrafinowanie (z elementami muzycznymi i teologicznymi) moniuszkowskiego myślenia kompozytorskiego.

Jako rodzaj initium tej części, w wezwania liturgiczne Moniuszko sukcesywnie ,wtapia” te kompilowane (oznaczone gwiazdką i pogrubieniem), w dynamice $p$ (t. 123-132): Sancta Maria - Sancta Mater Genitrix* Sancta Virgo Virginum - Sancta Mater Dei*. Pierwszą kulminację tworzą wezwania Virgo potens (t. 171, fff tutti) i Virgo fidelis (t. 175-177, fff - ff tutti). Główną fazę rozpoczyna zmiana tempa (z Molto agitato na Maestoso, wprowadzając duży kontrast), zmiana tonacji (z e na C), wraz z fanfarowym (niemal berliozowskim) „obwieszczeniem” (t. 195n, ff, ze smyczkami, całą blachą z 4 waltorniami i 3 puzonami oraz kotłami). Symbolizuje ono zapewne wielkość/majestat Wieży Dawidowej, ponieważ poprzedza wezwanie Turris Davidica (t. $197 \mathrm{n}, \mathrm{z}$ kontrastami dynamicznymi i cresc.), z - trzema kolejnymi. Po nich powraca nowe „główne” wezwanie Sancta Mater. Najpierw dwukrotnie powtórzone (t. 206-207, p pp tutti z kotłami), z rozbudowaną prośbą ora pro nobis (t. 208-221), prowadzącą do potężnej kulminacji. Powraca w niej po raz kolejny, tworząc finalny, „ekstatyczny” motyw (t. 222, fff tutti) i po raz ostatni w cichej, quasi melodii litanijnej: Sancta Mater, ora pro nobis (t. 226-230, p pp), zamykając tę część. 


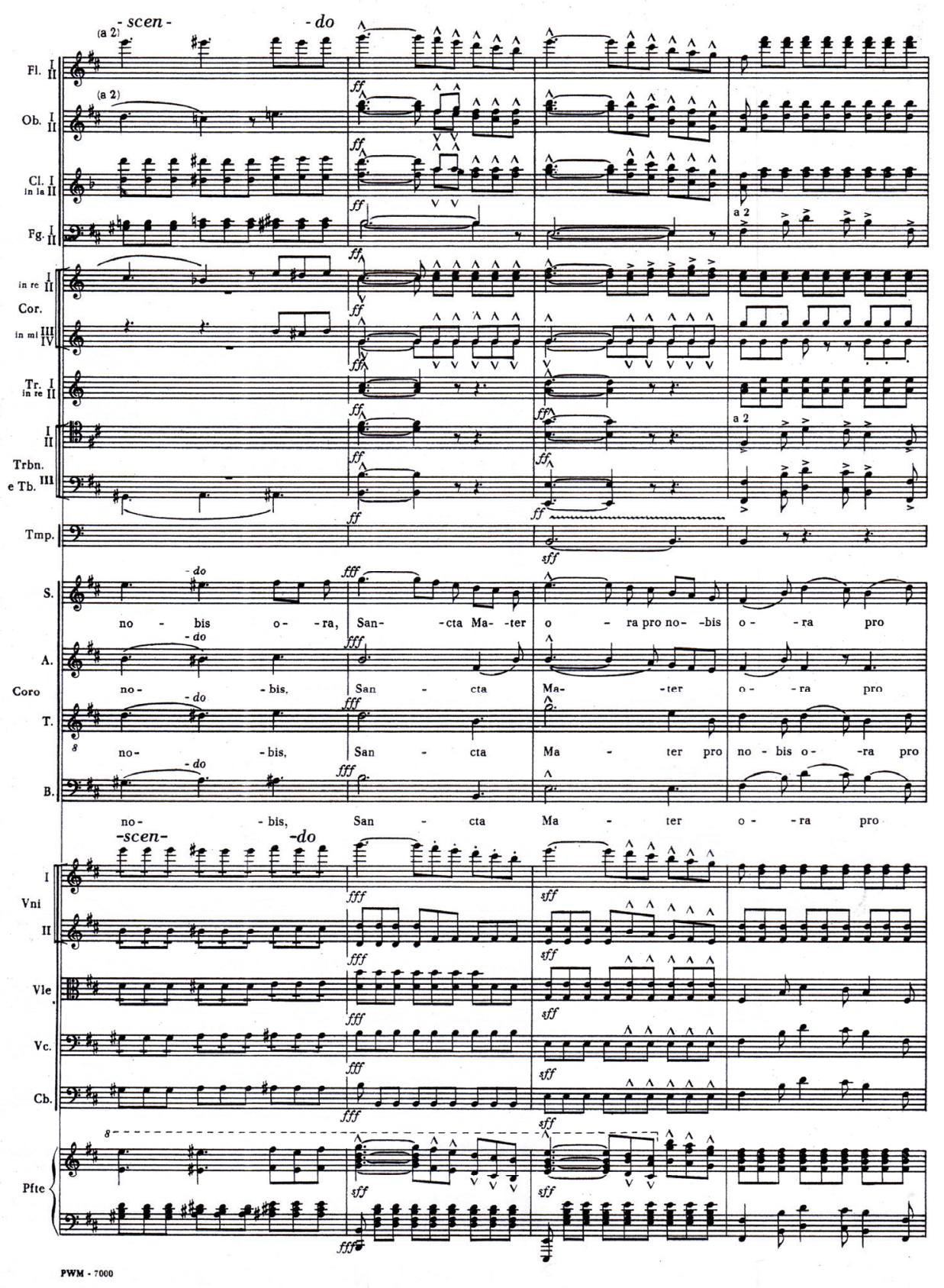

Przykład 1. III Litania Ostrobramska, cz. 3, t. 221-224, główna kulminacja.

Stanisław Moniuszko, Litanie Ostrobramskie, oprac. J. Berwaldt, Kraków 1972 
Moniuszko niewątpliwie świadomie eksponuje te przymioty „Matki”, które wskazują symboliczny związek z Ostrobramską Mater Misericordiae. Tak więc Sancta Mater może uosabiać Moc (tzn. spełniania próśb) i Wierność (z eksponowanych wezwań w pierwszej kulminacji), zaś Ostra Brama stawać się zarazem Wieżą Dawidową (z wezwania prowadzącego do głównej kulminacji). Niezwykle silne kontrasty ekspresyjne ${ }^{5}$ tej części ewokują różne typy modlitewne. Od supplicatio interna/ modlitwy wewnętrznej do dominujących supplicatio intensiva/modlitwy intensywnej i supplicatio extatica/modlitwy ekstatycznej (z wyróżnionych przeze mnie w monografii sześciu typów modlitewnych).

Jako rezultat niniejszych refleksji analitycznych, uznanie czterech Litanii Ostrobramskich za „muzykę wotywną”, pozwala dostrzec nie tylko ich mistrzostwo techniczne (monografia podkreśla kontekst europejskiej muzyki religijnej), lecz także przejrzystą koncepcję teologiczną, stworzenia przez kompozytora pełnej sumy muzycznej przymiotów Ostrobramskiej Mater Misericordiae, różnicowanych w poszczególnych Litaniach. Wydaje się to potwierdzać szczególny związek duchowy kompozytora z jego wielkim dziełem.

\section{„MODLITWA. DO CIEBIE, PANIE” \\ - SŁOWACKI W BENIOWSKIM PARODIUJE ZALESKIEGO}

Jest to zagadnienie dotychczas nieomawiane - związane zarówno z problematyką muzyczną, jak i literacką. Przemawia to za celowością tematycznego i metodologicznego (także różnych dyscyplin) poszerzania obszaru badań moniuszkowskich.

Polskie teksty religijnych pieśni Moniuszki są - jak wiadomo - poetyckimi modlitwami, co często bywa odnotowywane w tytule. Zwraca się też uwagę na liczbę mnogą wypowiedzi, odnoszącą się do zbiorowości jako podmiotu lirycznego (Gabryś 76) ${ }^{6}$. Ryszard Gabryś (w swoich dwóch książkowych publikacjach) generalnie nie ocenia wysoko ich poziomu literackiego: „(...) wiersze sprawiają wrażenie naprędce, okazjonalnie tworzonej poezji religijnej (...)”, zarzuca również „stereotypowe zwroty modlitewne” i „brak własnych przemyśleń i przeżyć poety" (77).

\footnotetext{
${ }^{5}$ Przede wszystkim szybkie tempo Molto agitato, ewokujące „intensywność błagania”, występujące w wielu litaniach różnych kompozytorów (także Mozarta), poczynając od okresu baroku. Trudno więc zrozumieć wspomniane zastrzeżenia Jachimeckiego (nazwanie tej części nawet „paradoksem muzycznym") i Opieńskiego.

${ }^{6}$ Autor wymienia 9 pieśni solowych Moniuszki do tekstów poetyckich.
} 
Ta ocena, o czym dalej, nie dotyczy zapewne wiersza „Do Ciebie, Panie” Józefa Bohdana Zaleskiego (Krzyżanowski, Hernas 665-666; Stelmaszczyk-Świontek 107-148; Weber 152-153) ${ }^{7}$, jedynego religijnego, autorstwa tego poety, jaki wybrał Moniuszko. Badacz ten zwraca uwagę na jego akcent patriotyczny (Gabryś 76). W ogóle niewiele wiadomo o tej pieśni. Nie ma o niej ani o Zaleskim żadnej wzmianki w listach Moniuszki. ${ }^{8}$

Tekst jest krótki, liczy zaledwie sześć wersów pisanych regularnym 11-zgłoskowcem, o postaci rymów abbacc (wyróżnienie słowa pochodzi z publikacji Duch od stepu):

Do Ciebie PANIE wznosim nasze modły, W drodze żywota znękani niezmiernie,

Albowiem wszystkie świata tego ciernie,

Kolcami na wskróś do serc nam przebodły.

Przecież o PANIE, nie nad nami PANIE!

Nad Matką Polską miej pożałowanie.

$\mathrm{W}$ tej błagalnej, poetyckiej modlitwie, uwagę zwraca wspomniany akcent patriotyczny (w dwóch ostatnich wersach): apostrofa do Pana Jezusa w intencji Ojczyzny - „Matki Polski.”

Okazuje się, że to wyraziste sformułowanie, uosabia manierę poetycką, charakterystyczną dla Zaleskiego. Maniera ta wraz z jego poezją stała się przedmiotem krytyki Juliusza Słowackiego, niewolnej od złośliwości. W artykule O poezji B. Z. (1841, opublikowany w 1884) zwrócił on uwagę, jak zostało to sformułowane w biogramie naukowym Zaleskiego, na m.in.: ,ciasnotę horyzontów umysłowych, ubóstwo myśli, czułostkowość, monotonię (...) środków wyrazu, liczne łatwizny”. Ponadto wskazuje się na „drwiące aluzje do utworów Zaleskiego", które Słowacki zawarł, m.in. w Beniowskim (zwłaszcza w Pieśni X,

\footnotetext{
${ }^{7}$ Poeta Józef Bohdan Zaleski (1802-1886), uczestnik Powstania Listopadowego, związany z zakonem Zmartwychwstańców. Pisał m.in. dumy historyczne, liryki miłosne i refleksyjne, poezję religijną; był „piewcą rodzinnej Ukrainy”. Łączył elementy sentymentalne i idylliczno-elegijne; uważa się też, że reprezentował romantyczną tradycję sentymentalną. Był ówcześnie niezwykle ceniony i bywał zaliczany przez krytykę do grona wieszczów. Cenił go Mickiewicz, także Norwid (z którym się przyjaźnił). Krytycznie odnosili się do jego twórczości Słowacki i Krasiński. Przyjaźnią darzył go Chopin, przyrzekając swojej uczennicy Zofii Rosengardt być świadkiem na ślubie z tym poetą (w paryskim kościele św. Rocha 28 listopada 1846 r.). Wybrał trzy jego wiersze, pisząc pieśni solowe (op. 74): „Śliczny chłopiec” (nr 8), „Dwojaki koniec” (nr 11), „Nie ma czego trzeba” (nr 13).

${ }^{8}$ Została wydana po śmierci kompozytora w zbiorze 6 pieśni z towarzyszeniem fortepianu (między 1873 a 1882) oraz w Jedenastym Śpiewniku Domowym (1908), w moniuszkowskim opera omnia (1974) oraz w innych zbiorach, m.in. 1998 (Rudziński, Prosnak 200; Rudziński Pieśni solowe; Stachel).
} 
w. 110-111, podano chyba błędnie w biogramie Zaleskiego). Także stwierdzenie, że „ogłoszony drukiem ów Duch od stepu, mocno wydrwiony przez Słowackiego" (Krzyżanowski, Hernas 666; Grzędzielska 90).

Jednak Jerzy Starnawski nazywając poetę „(...) najbardziej religijną naturą spośród tradycyjnej trójcy romantycznej”, w artykule poświęconym tematyce maryjnej w twórczości Słowackiego, zacytował czterowiersz z Beniowskiego ze wspomnianej wyżej Pieśni X (w. 111-114), nie odnosząc go w ogóle do poezji Zaleskiego. Natomiast badacz ten stwierdził (Starnawski 140, 135): „Jako Pani świata jest Matka Najświętsza opiekunką Polski. Do niej kieruje poeta apostrofę w Beniowskim:

O! Orędowniczko

Polski - Najświętsza Panno - o! kantyczko.

Zmiłuj się proszę - proszę nie nade mną,

Ale nad Polską miej ty zmiłowanie!".

Przecież o Panie, nie nad nami, Panie

Nad Matką Polską miej pożałowanie

[Słowacki, Beniowski]

[Zaleski, Do Ciebie, Panie]

Dopowiedzmy, że parodia Słowackiego polega na przekształconym cytacie dwóch wersów z wiersza Do Ciebie, Panie, przy zachowaniu maniery Zaleskiego (przywołano je dla możliwości porównania); pomimo zmiany adresata apostrofy - Pana Jezusa na „Najświętszą Pannę”, czytelnik musiał rozpoznać cytowanego autora i dostrzec intencję parodiującego. Jeśli rozszerzyć powyższy cytat (z artykułu Starnawskiego), „drwiąca aluzja” Słowackiego, jego parodia maniery Zaleskiego: sentymentalizmu i „czułostkowości” staje się w pełni widoczna9

${ }^{9}$ Zaleski był równie krytyczny w ocenie poezji Słowackiego. W jednym z listów (1841) wypowiadał się ,(...) o Beniowskim i jego autorze, że to «ogromna fantazja, a serca ani źdźbła», oraz że «wierszowanie świetne i żwawe», lecz «Nienawiść - jego Muza; a ja brzydkie Bogiem»." (Stelmaszczyk-Świontek 116). Poniższy cytat za Juliusz Słowacki, Beniowski, Pieśń X, w. 105-120, wolnelektury.pl:

Zwłaszcza jeżeli na świecie pochmurno,

Klnie świat... i nerwy! O! o! z krakowiaka

Zróbcie mi jakie posępne notturno ${ }^{843}$, $\mathrm{Z}$ notturna zróbcie coś alla polacca ${ }^{844}$,

Bo mi na świecie tem nadzwyczaj durno! Przyszła mi także z poczty cała paka

Lirycznych wierszy - O! Orędowniczko

Polski! Najświętsza Panno! o! kantyczko!

Zmiłuj się, proszę, proszę — nie nade mną, Ale nad Polską miej ty zmiłowanie!

Więcej nie mówię, bo mi od łez ciemno, I pod oknami także mam płakanie

Drzew, które słońca wołają daremno 
Nas interesuje jednak pieśń solowa skomponowana do tego tekstu przez Moniuszkę. W jej zapisie nutowym znajduje się znak repetycji - powtórzenia całej pieśni ze względu na krótki tekst. Nie wiadomo, skąd go przejął i czy wiedział, że jego wybór jest pierwszą strofą długiego jedenastozwrotkowego, pisanego sekstyną wiersza Zaleskiego Modlitwa za Polska (1837-1838), wydanego w zbiorze Duch od stepu. Przygrawka [!] do nowej poezji (Duch od stepu). $\mathrm{W}$ dwóch zwrotkach (poza pierwszą) powraca też końcowy wers w brzmieniu pierwszej strofy. W ostatniej, w której cała strofa jest bliskim wariantem pierwszej. Natomiast w siódmej, cała strofa skierowana jest do Jezusa w Trójcy Jedynego. Można by więc w przyszłej publikacji i w wykonaniu pieśni Do Ciebie, Panie jako repetycję uwzględnić tę strofę, zachowując intencję kompozytora (wyróżnienia słów pochodzą z publikacji Duch od stepu):

JEZU nasz JEZU - o w TRÓJCY JEDYNY!

TYŚ uczył: «Proście a będzie wam dano.»

Prosim za matką - wróć jej wiano - miano!

Baranku, który gładzisz świata winy -

Bądź miłosierny! nie nad nami PANIE,

Nad matką Polską miej pożałowanie.

Niezależnie od parodii Słowackiego wiersz Zaleskiego i cały zbiór, w którym został opublikowany, reprezentuje ważną dla jego poezji, nową i silniej zaznaczającą się postawę religijną (zob. przyp. 10). Łączy się w niej w sposób szczególny tematyka religijna z narodową. Właściwie obie się wzajemnie dopełniają. Między innymi Modlitwa za Polska jest aktem „religijnej pokory”. Mickiewicz ocenił wysoko zbiór Duch od stepu, „zaliczając go do poezji nowej, proroczej" (Stelmaszczyk-Świontek, 125-127, 132) ${ }^{10}$.

Pieśń solowa Moniuszki jest utworem wartościowym zarówno literacko, jak i muzycznie. Z krótkim wstępem (4-taktowym) i regularną budową trzyzdaniową (po 8 taktów): aalb; drugie zdanie rozwija myśl muzyczną i tekstową pierwszego, trzecie zaś - pełni funkcję quasi-refrenu. Pieśń, to pełne prostoty liryczne ariozo, typ skupionej modlitwy wewnętrznej/supplicatio interna - utrzymanej w duchu wspomnianej „religijnej pokory”, jak można by dopowiedzieć. Rozwijanej w wolnym tempie (Adagio), w tonacji mollowej (f), $\mathrm{z}$ wyrazistym motywem ascenden-

I mają z liścia złotego ubranie...

Jesień z liryzmem smutnym przyszli w parze

Na moją duszę, jako dwaj grabarze.

${ }^{10}$ Niekiedy jednak kwestionuje się szczerość tej oceny. Można spotkać także stwierdzenie ogólniejsze, że: „Niedostatek inspiracji epickich Zaleski usiłował wymodlić. Odbywał tedy dla podniesienia ducha rekolekcje u trapistów, które niewiele wszakże mu pomagały" (Grzędzielska 91). 
talnym (na rozłożonym trójdźwięku) integrującym formę; on rozpoczyna dwa zdania i tworzy kulminację we wspomnianym refrenie (ze zmianą trybu na jednoimienny durowy F). Z główną myślą „modlitwy”: „Nad Matką Polską miej pożałowanie", która może tworzyć też rodzaj duchowego motta moniuszkowskiego gatunku pieśni religijnej.
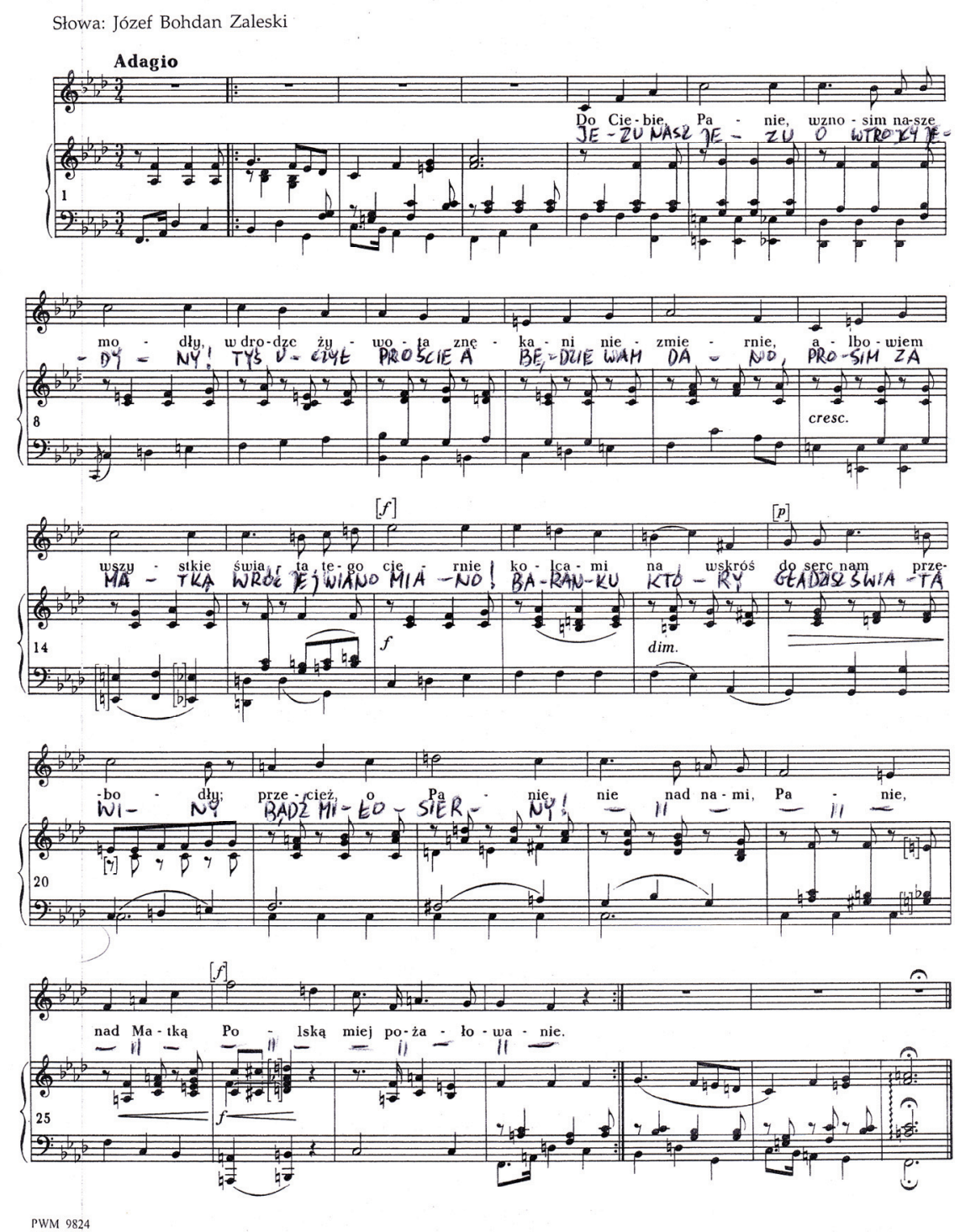

Przykład 2. Do Ciebie, Panie, z dopisanym tekstem. Stanisław Moniuszko, Pieśni religijne, utwory solowe i duety z towarzyszeniem organów lub fortepianu, red. I. Stachel, Kraków 1998 


\section{DO MONIUSZKOWSKICH BADAŃ/O POSTAWACH BADAWCZYCH}

Na zakończenie: autora monografii i prac poświęconych muzyce religijnej Moniuszki - krótka glosa krytyczna, związana z badaniami ${ }^{11}$.

Określenie Litanie Ostrobramskie występuje w postaci wariantu tytułu (w liczbie pojedynczej) jako Litania do Ostrej Bramy - utworu wcześniejszego, skomponowanego przez Józefa Deszczyńskiego (1781 - 1844). Tenże utwór, napisany do polskiego tekstu Litanii loretańskiej, odnalazła w 2008 r. (w Narodowej Bibliotece w Wilnie) badaczka i organistka białoruska dr Swiatłana Niemahaj. Sporządziła jego partyturę i doprowadziła do wykonania, które odbyło się 5 marca 2011 r. w Białymstoku (Aula Magna Pałacu Branickich) przez Zespół Wokalny Camerata Podlaska i Orkiestrę Kameralną pod dyr. Bożeny Bojaryn-Przybyły. W ten sposób ten wartościowy historycznie utwór, chronologicznie tworzący także moniuszkowską tradycję litanijną, stylowo wykonany, został przywrócony polskiej religijnej kulturze muzycznej I poł. XIX wieku.

Badaczka ta rok przed tym wykonaniem (2010) opublikowała artykuł w czasopiśmie Białoruskiej Państwowej Akademii Muzyki, określając w tytule tę litanię, napisaną trzeba pamiętać do polskiego tekstu, jako „pomnik religijnej kultury Białorusi" (Nyemahay 20-29).

W tekście artykułu Deszczyńskiego nazwała „kompozytorem, dyrygentem i pedagogiem Białorusi I poł. XIX w." (Nyemahay 20), w ogóle nie uzasadniając tych atrybucji białoruskich. Natomiast w czasopiśmie litewskim, w artykule (poświęconym tej litanii) w języku rosyjskim (2013), w tytule nie pojawiło się już to określenie (zapewne $\mathrm{z}$ racji wileńskiego rodowodu Deszczyńskiego), lecz sformułowanie o charakterze historycznym ,przedromantyczna poprzedniczka litanii S. Moniuszki” (Nemogay 185-206). Oficjalnie w 2015 r. opublikowany został w redakcji zbiorowej przekaz nutowy tej litanii (w opracowaniu na chór i fortepian) ze zmienionym tytułem białoruskim Bacmpaбрамская літанія i tekstem w języku białoruskim; sygnowany przez Ministerstwo Kultury Republiki Białorusi, Narodowy Akademicki Teatr Wielki Opery Republiki Białorusi i zespół artystyczny „Białoruska Kapela”; redaktorem naukowym i rekonstruktorem tekstu nutowego oraz autorem przedmowy jest dr Swiatłana Niemahaj. W przedmowie tej (mówiąc najogólniej) nie wspomina o polskiej genezie kultu Maryi Ostrobramskiej (zainicjowanego przez karmelitów bosych), ograniczając się do jego białoruskiej prawosławnej tradycji (używając przy tym, co można zrozumieć, ekspresyjnych sformułowań);

${ }^{11}$ Wyrażam podziękowanie dr hab. Bożenie Bojaryn-Przybyle i ks. dr. hab. Zbigniewowi Stępniakowi. 
natomiast w „polskojęzycznych”, jak to określa, tekstach pieśni religijnych zwraca uwagę na „owoce tradycji i kultury litewskiej.” Moniuszkę nazywa „naszym [tzn. białoruskim] rodakiem”. Natomiast Deszczyńskiego (urodzonego w Wilnie), określa tym razem jako „wybitnego kompozytora”, „znanego nie tylko na terenach byłej Rzeczypospolitej, lecz także za granicą" (Vastrabramskaya litaniya $3 \mathrm{n}$.).

Jestem przekonany, że Litania do Ostrej Bramy może być opublikowana także w Polsce. W pełnej obsadzie wykonawczej, w wydaniu źródłowym, oddającym wkład pracy tej badaczki. Z komentarzem dokumentującym historyczną tożsamość kulturową dzieła.

Badaczka ta jest także zapraszana na konferencje i koncerty w Polsce. Powołano ją do Komitetu Naukowego PWM dzieł wszystkich Moniuszki. W biogramie oficjalnym (na portalu moniuszko200.pl) podkreśla swoje wieloletnie badania i „propagowanie twórczości Moniuszki na Białorusi”, lecz nie wspomina, że w jej rodzimej literaturze naukowej Moniuszko jest kompozytorem Białorusi - „,naszym rodakiem” (z cytowanej przedmowy).

Moje zainteresowanie wzbudził też tekst prof. Magdaleny Dziadek Lirnik wioskowy kontra wieszcz (1-2). Tym bardziej, że jest on $\mathrm{z}$ założenia adresowany do szerokiego kręgu czytelników. Wprawdzie sprzed roku, lecz w wypowiedziach autorki prac naukowych poświęconych Moniuszce (m.in. jego recepcji) wiąże się z aktualnymi badaniami moniuszkowskimi. Nie oceniam rezultatów badań autorki. Moje wątpliwości odnoszą się do niektórych sformułowań metodologicznych zawartych w tym tekście. Popularyzowanych przez autorkę, intencjonalnie wpływających na szeroki odbiór społeczny. Z konieczności ograniczę je do zwięzłych uwag.

Przede wszystkim postulat zbudowania ,prawdziwego wizerunku Moniuszki jako twórcy i człowieka." W takim sformułowaniu można go odczytać jako dyrektywę odgórną bardziej, niż koncepcję badań naukowych. Tym bardziej, jeśli interpretacje źródłowe brzmią niemal kategorycznie. Gdyby np. lektura starej edycji listów kompozytora była „uważna i bezstronna”, można by zobaczyć, jak pisze autorka: „zupełnie innego Moniuszkę niż ten, przed którym stają dziś na baczność uczniowie i ministrowie". Wyczuwa się w tym „wojskowym” zwrocie poirytowanie autorki. Dopowiada więc, m.in., że Moniuszko „władał w pełni” tylko rosyjskim, „,wyziera z listów kompletny brak sprytu życiowego". I wreszcie „rygorystycznie pojmował reguły życia w zgodzie z dekalogiem”. Wymienione cechy, zdaniem autorki „skutecznie utrudniły kompozytorowi poruszanie się w środowisku muzycznym."

Komentując obecne w tych stwierdzeniach kategoryzowanie, można przypomnieć, że mało życiowy był też Norwid z jego emanacją życiową dekalogu. 
Dwukrotnie starał się bezskutecznie o przyjęcie do zgromadzenia Zmartwychwstańców; nie został nawet jego świeckim konfratrem. Nie miało to jednak żadnego wpływu na wartość jego dzieła.

W całym tekście budzi mój metodologiczny sprzeciw jednostronny sposób przybliżenia czytelnikowi twórczości Moniuszki. Wymieniając poszczególne formy oraz utwory, autorka nie mówi bezpośrednio, przystępnie o ich ocenie aksjologicznej - większej lub mniejszej wartości wynikającej z badań. Powołuje się natomiast na opinie różnej proweniencji wygłaszane o tych dziełach, tworzące jedynie ich recepcję. Im bardziej dominuje w nich „lirnik wioskowy kontra wieszcz” (lub na odwrót) - chociaż Moniuszko nigdy tak siebie nie nazwał - tym w większym stopniu jego dzieło pozostaje nieobecne, wręcz znika.

Czemu ma służyć brak w tym popularyzatorskim artykule aksjologii dzieła Moniuszki (tzn. jego wartości wywiedzionej z analizy) wyraźnie odróżnianej i oddzielanej od jego oceny w recepcji (tzn. „co o wartości dzieła sądzono”)?

Aktualna pozostaje dumna (jak to określają badacze) prośba Cypriana Norwida (zm. 23 maja, z ostatniego listu, z 16 marca 1883 r.) wraz z nadzieją na jej wypełnianie. Można ją odnieść, jako źródło z epoki, również do Moniuszki: „C.N. [S.M., dodajmy także] zasłużył na dwie rzeczy od Społeczeństwa Polskiego: to jest, ażeby oneż społeczeństwo nie było dlań obce i nieprzyjazne”.

\section{BIBLIOGRAFIA}

\section{ŹRÓDŁA}

Almanach Moniuszkowski 1872-1952, red. Witold Rudziński i Jan Prosnak, Czytelnik, 1952.

Dashchynski, Yuzaf. Vastrabramskaya litaniya (Noty): dlya salistaw, zmyeshanaha khoru i simfanichnahaarkyestra, nav. redaktar S. Nyemahay, muz. redaktar U. Baydaw, H. Karzhanyewskaya, S. Nyemahay i N. Lamanovich, Ministerstva Kul'tury Respubliki Byelarus', Natsyyanal'ny akademichny Vyaliki teatr opyery Respubliki Byelarus', tvorchy kalyektyw «Byelaruskaya kapela», 2015 [Дашчынскі, Юзаф. Вастрабрамская літанія (Ноты): для салістай, змешанага хору i сімфанічнага аркестра, нав. рэдактар С. Немагай, муз. рэдактар У. Байдаў, Г. Каржанеўская, С. Немагай і Н. Ламановіч, Міністэрства культуры Рэспублікі Беларусь, Нацыянальны акадэмічны Вялікі тэатр оперы Рэспублікі Беларусь, творчы калектыў «Беларуская капэла», 2015].

Duch od stepu. Przygrawka [!] do nowej poezji przez Bohdana Zaleskiego. Wyd. 2. Paryż, Księgarnia Luxemburgska, 1867.

Liber Usualis Missae et Officii. Desclée, 1956.

Moniuszko, Stanisław. Dzieła. T. 6, Pieśni solowe i duety z organami lub orkiestra, opracowania organowe śpiewów religijnych, red. Witold Rudziński, wyd. Erwin Nowaczyk, Polskie Wydawnictwo Muzyczne, 1974. 
Moniuszko, Stanisław. Litanie Ostrobramskie, oprac. Jacek Berwaldt, Polskie Wydawnictwo Muzyczne, 1972.

Moniuszko, Stanisław. Pieśni religijne, utwory solowe i duety z towarzyszeniem organów lub fortepianu, red. Irena Stachel, Polskie Wydawnictwo Muzyczne, 1998.

Rudziński, Witold, red. Stanisław Moniuszko. Listy zebrane. Polskie Wydawnictwo Muzyczne, 1969.

Słowacki, Juliusz. Beniowski. Poema: pięć pierwszych pieśni. Lipsk, Leopold Michelsen, 1841.

Słowacki, Juliusz. Pisma pośmiertne, [pieśń 6-10]. T. 2, Lwów, A. Małecki, 1866.

\section{LITERATURA}

Bebak, Marek. „Homo religiosus. Twórczość religijna Stanisława Moniuszki w kontekście jego postawy życiowej i wobec dziewiętnastowiecznego kryzysu muzyki kościelnej”. Życie twórczość - konteksty. Eseje o Stanisławie Moniuszce, red. Magdalena Dziadek, Narodowe Centrum Kultury, 2019, ss. 143-169.

Dąbek, Stanisław. „Offertorium „Deus meus, ne in furore tuo” (ps. 38) z Mszy Des- dur Stanisława Moniuszki w kontekście pobożności okresu romantyzmu". Additamenta Musicologica Lublinensia, nr 1, 2005, ss. 57-67.

Dąbek, Stanisław. Twórczość litanijna Stanisława Moniuszki i jej konteksty. Wydawnictwo Uniwersytetu Muzycznego Fryderyka Chopina, 2011.

Dąbek, Stanisław. „Nowa metodologia, nowe spojrzenie na Litanie Ostrobramskie Stanisława Moniuszki”. Myśli o języku, nauce i wartościach. Seria druga. Profesorowi Jackowi Juliuszowi Jadackiemu w siedemdziesiąta rocznicę urodzin, red. Anna Brożek [i in.], Wydawnictwo Naukowe Semper, 2016, ss. 398-402.

Dąbek, Stanisław. „Missa de Lisieux Feliksa Nowowiejskiego - wotum ku czci św. Teresy”. [artykuł przyjęty do druku w pracy zbiorowej, red. Aleksandra Kłaput-Wiśniewska, Wydawnictwo Akademii Muzycznej im. Feliksa Nowowiejskiego]

Dąbek, Stanisław. „Muzyka kościelna Stanisława Moniuszki: gatunek - typologia - funkcja aksjologia”. [artykuł przyjęty do druku w pracy zbiorowej, red. Marcin Gmys]

Dąbek, Stanisław. „»Tekst« a »słowo« w formach muzyki kościelnej Stanisława Moniuszki. Zarys metodologii i założenia analizy." [artykuł przyjęty do druku w pracy zbiorowej, red. Alicja Gronau, Wydawnictwo Uniwersytetu Muzycznego Fryderyka Chopina]

Dziadek, Magdalena. „Lirnik wioskowy kontra wieszcz”. Silesia, nr 159, 2019, ss. 1-2.

Gabryś, Ryszard. Religijna pieśń solowa w twórczości kompozytorów polskich XIX wieku. Wydawnictwo Akademii Muzycznej im. Fryderyka Chopina, 1998.

Grzędzielska, Maria. „Tęcza siedmiostrunna. Józef Bohdan Zaleski - Cyprian Norwid”. Studia Norwidiana, nr 3-4, 1985-1986, ss. 85-115.

Krzyżanowski, Julian i Czesław Hernas. Literatura Polska. Przewodnik encyklopedyczny. T. 2, Państwowe Wydawnictwo Naukowe, 1985, ss. 665-666.

Nyemahay, Svyatlana Mikalayewna. „Vostrabramskaya litaniya Yuzafa Dashchynskaha - pomnik relihiynay muzyki Byelarusi chasow pyeradramantyzma.” Vyestsi Byelaruskay dzyarzhawnay akademii muzyki, nr 17, 2010, ss. 20-29 [Немагай, Святлана Мікалаеўна. „Вострабрамская літанія Юзафа Дашчынскага - помнік рэлігійнай музыкі Беларусі часоў перадрамантызма". Весиі Беларускай дзяржаўнай акадэміі музыкі, №17, 2010, сc. 20-29].

Nemogay, Svetlana. „Ostrobramskaya litaniya Yuzefa Deshchinskogo - predromanticheskaya predshestvennitsa litaniy S. Monyushko.” Menotyra, t. 20, nr 3, 2013, ss. 185-206 [Немогай, 
Светлана. „Остробрамская литания Юзэфа Дещинского - предромантическая предшественница литаний С. Монюшко”. Menotyra, t. 20, nr 3, 2013, ss. 185-206].

Rudziński, Witold. „Twórczość maryjna Stanisława Moniuszki”. Matka Boska w życiu i twórczości wielkich Polaków, t. 1, red. Teofil Herrmann, Centralny Ośrodek Apostolatu Maryjnego, 1995, ss. $151-174$.

Starnawski, Jerzy. „Motywy maryjne w twórczości Słowackiego”. Matka Boska w życiu i twórczości wielkich Polaków, t. 1, red. Teofil Herrmann, Centralny Ośrodek Apostolatu Maryjnego, 1995, ss. 135-150.

Stelmaszczyk-Świontek, Barbara. „O poezji Bohdana Zaleskiego z lat emigracji: tradycja sentymentalna w romantyzmie polskim”. Pamiętnik Literacki, nr 3, 1981, ss. 107-148.

Walicki, Aleksander. Stanisław Moniuszko. Warszawa, [Skład główny] Gebethnera i Wolffa, 1873.

Weber, Bożena. Chopin. Wydawnictwo Dolnośląskie, 2003.

\section{GLOSY DO BADAŃ MONIUSZKOWSKICH}

\section{Streszczenie}

Artykuł obejmuje trzy glosy. Pierwsza dotyczy uznania Litanii Ostrobramskich Stanisława Moniuszki za „muzykę wotywną.” Spełniają one kryteria, m.in.: tytułu utworu, intencji kompozytora, funkcji liturgicznej i symbolicznego atrybutu wotywnego - wprowadzenia do tekstu Litanii loretańskiej nowego wezwania Sancta Mater, odnoszącego się zapewne do Ostrobramskiej Matki Miłosierdzia. Kolejna glosa dotyczy parodii zawartej w poemacie Beniowski Juliusza Słowackiego, z tekstu wiersza Do Ciebie, Panie Józefa Bohdana Zaleskiego. Autor omawia religijną pieśń solową Moniuszki, skomponowaną do tego tekstu. Artykuł kończy krótka glosa odnosząca się krytycznie do badań nad Moniuszką.

Słowa kluczowe: Stanisław Moniuszko; muzyka wotywna; symboliczne atrybuty wotywne; poemat Beniowski; parodia; religijna pieśń solowa.

\section{COMMENTARIES ON MONIUSZKO RESEARCH}

\section{Summary}

This article consists of three commentaries. The first concerns the recognition of Stanisław Moniuszko's Litanies of Ostra Brama as "votive music". These Litanies meet the criteria of having, amongst other things, a title to the piece, the intentions of the composer, a liturgical function and a symbolical votive attribute, namely the introduction of a new invocation titled Sancta Mater, which undoubtedly refers to the Mother of Mercy of Ostra Brama, to the text of the Litany of the Blessed Virgin Mary. Another commentary draws attention to the parody contained in the narrative poem Beniowski by Juliusz Słowacki, taken from the text of the poem Do Ciebie, Panie/To You, Lord by Jozef Bohdan Zaleski. The author discusses Moniuszko's religious solo song, which was specially composed for this text. The article ends with a short commentary related to current research on Moniuszko and the basis for further research.

Key words: Stanisław Moniuszko; votive music; symbolic votive attributes narrative; poem Beniowski; parody; religious solo song. 